\title{
Impact of gas and oil-fired power plants on proximal water and soil environments: case study of Egbin power plant, Ikorodu, Lagos State, Nigeria
}

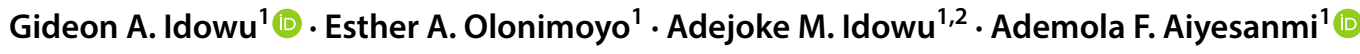

Received: 15 May 2020 / Accepted: 25 June 2020 / Published online: 8 July 2020

(c) Springer Nature Switzerland AG 2020

\begin{abstract}
Thermal power plants utilizing gas and/or fuel oil are widespread globally and are fast replacing coal-fired plants in many regions. In this study, we investigated the impact of Egbin thermal power station (a gas and oil-fired plant situated in Lagos State, Nigeria) on physico-chemical characteristics and trace metals concentration of the proximal lagoon water, sediment, soil and biota. Temperature of the water ranged from 29.7 to $30.1{ }^{\circ} \mathrm{C}$ and reflected the influence of the power plant operations. Dissolved oxygen ranged from 5 to $8 \mathrm{mg} / \mathrm{L}$, increasing steadily with distance away from the power plant. Highest concentration of $\mathrm{As}, \mathrm{Cd}, \mathrm{Cr}, \mathrm{Hg}, \mathrm{Pb}$ and $\mathrm{Zn}$ were measured in water and corresponding sediment from sampling point closest to the power plant. Furthermore, concentration of $\mathrm{As}, \mathrm{Cd}, \mathrm{Cr}$ and $\mathrm{Pb}$ in the lagoon water decreased steadily with distance away from the plant, strongly indicating that their levels in the lagoon are influenced by operations of the power plant. Atmospheric deposition of pollutants was responsible for $\mathrm{Cr}$ presence in proximal soil samples. Analysis of trace metals in biota species obtained from the lagoon provide evidence of bioaccumulation of $\mathrm{Cd}$, $\mathrm{Pb}, \mathrm{Hg}$ and $\mathrm{Zn}$ in crabs (Callinectes amnicola) and shrimps (Penaeus notalis), important sources of protein for inhabitants of coastal communities in the area. In addition to revealing a route of human exposure to sub-lethal doses of potentially harmful metallic elements, the study would be useful in predicting the impact of gas and oil-fired power plants in other geographical regions.
\end{abstract}

Keywords Environmental impact · Egbin power plant · Gas and fuel-oil · Water · Soil · Sediment

\section{Introduction}

Energy is essential to a nation's economic development and it is the wheel that drives most aspects of everyday life. Electricity, more than any other form of energy, plays a central and versatile role in modern society, with applications cutting across various fields, including health and medicine, transportation, telecommunication, industrial production, trade and commerce, education, research, sports, entertainment and security. Its flexibility, relative low cost, and most importantly, high transmission efficiency, make it the energy of choice for these various purposes [1, 2]. However, it is unavailable in any useful quantity in nature and is thus generated from readily available primary sources (such as hydro and tidal power, geothermal power, chemical power, wind power, nuclear power and solar power), usually by converting them, first Electronic supplementary material The online version of this article (https://doi.org/10.1007/s42452-020-3150-0) contains
supplementary material, which is available to authorized users.

$\triangle$ Gideon A. Idowu, gaidowu@futa.edu.ng |' Department of Chemistry, Federal University of Technology, P.M.B 704, Akure, Ondo State, Nigeria. ${ }^{2}$ College of Health Science and Technology, P.M.B. 530, Ondo, Ondo State, Nigeria. 
to mechanical work/energy, which is then converted to electrical energy.

Of the various possible primary energy sources for electricity production, the vast majority of power stations have been built to utilize chemical energy. This energy, lurked in coal, natural gas and fuel-oil, is released via combustion of these fuels in boiler of thermal power plants, where heat is generated to convert water to steam. The high-temperature, high-pressure steam is used to drive the shaft of a turbine to generate mechanical energy, which is subsequently converted to electrical energy, that is transmitted out of the plant [3]. The steam used in the turbine is condensed by releasing part of the heat to a mass of cooling water, before the condensate (hot water) is recycled into the boiler. Given the huge amount of fuel and water consumed on daily basis, and the enormous amount of heat and wastes released continuously; the operations of thermal power plants undoubtedly have implications on the environment, especially with respect to temperature alterations, pressure on water demand, release of organic pollutants, and release of toxic gases and trace metals from fuel combustion.

In particular, concerns over excessive pollution of the environment, due to $\mathrm{CO}_{2}$, trace metals and particulate matter emissions from coal-fired plants, have caused a reduction in coal and peat dependence for electricity generation over the past decades, while the use of natural gas and renewable sources increased simultaneously over the period. Currently, coal accounts for about $38.4 \%$ of the world's electricity generation, while input from gas has risen to about $23.2 \%$, with gas-fired plants replacing coal-fired ones in many countries [4,5]. Hydropower generation contributes $16.3 \%$, and uranium (nuclear power) and fuel-oil account for $10.4 \%$ and $3.7 \%$, respectively. Use of non-hydro renewable sources (wind, solar, geothermal and biogas) currently stands at a total of $8 \%$ [4].

Like coal, natural gas and fuel-oil are fossil fuels, and also contain traces of chemical substances which can potentially contaminate the environment upon their combustion. However, the vast majority of studies investigating the effects of thermal power plants on the environment have focused on the coal-fired plants [6-12], apparently because earlier thermal power stations utilized coal as fuel. To date, little attention has been given to gas and oil-fired power stations and scientific reports on their specific environmental impacts are limited. Two studies, by Yang and co-workers [13] and Fouladi and co-workers [14], have examined air quality in the surroundings of gas-fired plants, with respect to particulate matter emissions and gaseous pollutants, such as nitrogen oxides, $\mathrm{CO}$ and $\mathrm{SO}_{2}$, and reported human health effects ranging from chronic bronchitis to long-term mortality. Few other studies have also focused on direct human health effects, such as noise-induced hearing impairment, emergency hospital visits and hospital admissions, as a result of proximity of humans to gas-fired plants $[15,16]$.

In the current study, an investigation was carried out into the environmental effects of Egbin thermal power station, a gas and oil-fired steam plant, located in Lagos, Southwestern Nigeria. The power station is situated on the riverbank of a lagoon (Lagos lagoon), flowing along ljede community in Ikorodu, a cosmopolitan city in the outskirt of Lagos. Although the plant releases waste water to a side of the lagoon where impacts are expected to be most pronounced (and is therefore strictly restricted from public access), the characteristic heavy, turbulent, and 'back-and-forth' flow of the lagoon water, means that any contaminants introduced into the lagoon could potentially be transferred to the other side of the plant. In addition, exhausts and smoke stacks of the plants regularly spew fumes into the atmosphere, with potential to contaminate the surrounding environment. Thus, we investigated the concentration of potentially toxic trace metals $(\mathrm{As}, \mathrm{Cd}, \mathrm{Cr}$, $\mathrm{Hg}, \mathrm{Pb}, \mathrm{Zn}$ ) in water, sediments, soil, and biota samples on the accessible side of Egbin power plant. Physicochemical characteristics of the various sample matrixes were also determined to understand any impacts of the plants' activities on them, and to examine their possible association with the trace metal contaminants.

\section{Materials and methods}

\subsection{The study area}

Egbin thermal power station is the largest electricity generating station in Nigeria and in the West African subregion. It contributes between 30 and $40 \%$ of the total available power on the national grid. It is a steam power plant, located at ljede in lkorodu (latitude $6^{\circ} 33^{\prime} 47^{\prime \prime} \mathrm{N}$; longitude $3^{\circ} 36^{\prime} 55^{\prime \prime} \mathrm{E}$ ), and about $40 \mathrm{~km}$ Eastward of Lagos metropolis, in the Southwestern part of Nigeria. The power station has a total installed capacity of 1320 megawatt (MW), consisting of six boiler turbine units, each coupled to a generator motor rated at $3000 \mathrm{rpm}$ and capable of producing $220 \mathrm{MW}$ of electricity at maximum performance [17]. The boiler units, each generating up to 705 tonne of steam per hour, are designed for dual firing of both natural gas and low/high pour fuel-oil (LPFO/HPFO) $[17,18]$.

The situation of the power station at ljede, along the bank of the Lagos lagoon, satisfies important logistic purposes. First, it facilitates easy transmission of electricity to Lagos, the most populous Nigerian and West-African city, which also serves as the industrial and commercial hub of the nation. Indeed, the city is one of the fastest growing and most populous urban centers of the world 
[19]. Secondly, it provides easy access to the lagoon, from which water is diverted into the turbines for cooling, and which also serves as a medium to receive warm water from the cooling operation. The lagoon is the largest of four lagoon systems of the Gulf of Guinea and stretches to a length of about $257 \mathrm{~km}$ from Cotonou, in Benin Republic, to the Western end of Niger Delta in Nigeria. The depth around Lagos is quite shallow, at a maximum of $6.4 \mathrm{~m}$, apart from dredged portions, where depth up to $25 \mathrm{~m}$ may be found [20]. The lagoon empties into the Atlantic Ocean through Lagos Harbour, a $1 \mathrm{~km}$ wide channel in the heart of the metropolis.

\subsection{Sampling of water, sediment, biota and soil}

Samples of water and corresponding sediments were taken from 5 points on the lagoon, near the location of Egbin power plant, and via the side accessible to the public. To investigate the impact of the power station on the surrounding environment, we hypothesized that values of indicator parameters (e.g. trace metals concentration) should be relatively high in environmental matrixes near the power station and decrease with increasing distance away from the plant. Thus, starting from point 1 on the lagoon ( $6^{\circ} 33^{\prime} 38.9^{\prime \prime}$; E $3^{\circ} 36^{\prime} 07.7^{\prime \prime}$ ), the closest possible point to the power station, the first water (W1) and sediment (SD1) samples were obtained. Four additional water samples (W2 to W5) and corresponding sediments (SD2 to SD5) were then taken with increasing distance away from the plant (point 2 to point 5). Figure 1 shows a map of the studied section of the lagoon and the 5 points at which the samples were taken. In parallel to the water and sediment samples, topsoil (0-15 cm depth) and subsoil (15-30 cm depth) were taken from points 1 to 5 on the adjacent land, corresponding to the points 1 to 5 on the lagoon. Distance of each soil sampling point was $100 \mathrm{~m}$ sideward of the lagoon water. All the water, sediment and soil sampling points were within $2 \mathrm{~km}$ distance of the power plant. Control top and subsoil samples $\left(S_{c t r}\right)$ were taken from a farther location, within the ljede community, $6 \mathrm{~km}$ westward of the power plant.

Sampling of the water, at each point on the lagoon, was performed by taking three $1 \mathrm{~L}$ portions, and combining them into a composite sample in a pre-wash polypropylene bottle. The resulting sample was divided into two equal parts. The portion used for trace metals analyses was acidified to $0.25 \mathrm{M}$ with conc. $\mathrm{HNO}_{3}(99.9 \%$ pure based on trace metals content, Sigma-Aldrich) and refrigerated at $4{ }^{\circ} \mathrm{C}$ prior digestion. The unacidified half portion was used for physicochemical analyses. Similar to the water sampling, three sediment columns at depths of $15 \mathrm{~cm}$ were collected at each point, using Ekman dredge grab sampler, and combined in a polyethylene bag to give a composite sediment sample for that point. All the sediment samples were air-dried in the laboratory at room temperature, ground, and sieved through a $2 \mathrm{~mm}$-size mesh. Soil samples were collected using a graduated standard soil auger into clean polyethylene bags, and were treated like the sediment samples.

Fishermen found working on the lagoon were engaged to capture three biota types: tilapia fish (Oreochromis niloticus), crab (Callinectes amnicola) and shrimp (Penaeus notalis). Three pieces or samples of each biota species were caught and were frozen prior to oven-drying in the laboratory. Each piece of biota type was then macerated separately in a blender and digested for trace metals analysis. All samples (water, sediment, soil and biota species) were collected the same day, during the rainy season in June 2019.
Fig. 1 Map of the study area near Egbin thermal power station, located on the bank of Lagos Lagoon in ljede community, Ikorodu, Nigeria

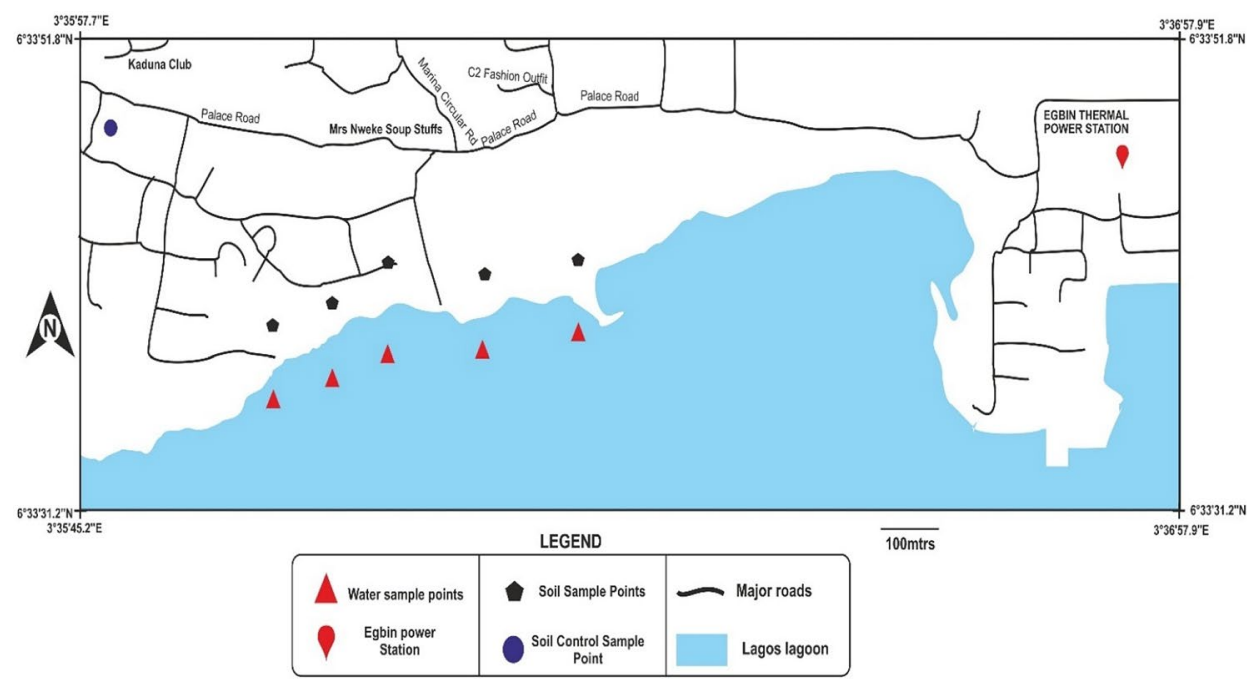

SN Applied Sciences A SPRINGER NATURE journa 


\subsection{Physicochemical analyses of water samples}

Temperature, $\mathrm{pH}$ and dissolved oxygen (DO) of the water samples were determined in situ. Temperature and $\mathrm{pH}$ were measured using a microprocessor meter (HANNA Instruments Ltd., Germany). The meter was calibrated with buffers 4 and 9 prior to $\mathrm{pH}$ measurement. DO was determined with a HANNA DO test kit, and the analysis was repeated to determine biological oxygen demand (BOD), following incubation of the samples for 5 days in the dark. $B O D$ was the difference between the initial DO measured on site and that measured 5 days later [21]. Conductivity was determined with a digital conductivity meter (Babtech Ltd., India), calibrated with $1 \mathrm{M} \mathrm{KCl}$ solution at $25^{\circ} \mathrm{C}$.

Total solids (TS) and total dissolved solids (TDS) were determined by gravimetric method using $100 \mathrm{~mL}$ of unfiltered and filtered samples, respectively. Total suspended solids (TSS) was calculated as the difference of TS and TDS. Chemical oxygen demand (COD) and alkalinity were determined by titrimetric methods, using ferrous ammonium sulphate and sulphuric acid, respectively, as described by Ademoroti [21].

\subsection{Physicochemical analyses of sediment and soil samples}

$\mathrm{pH}$, temperature and conductivity of wet sediment samples $(10 \mathrm{~g})$ were determined in situ with the same meters used for the water samples. For the soil samples, $20 \mathrm{~mL}$ of distilled-deionized water was added to $10 \mathrm{~g}$ of dried and sieved sample and the mixture was stirred for $30 \mathrm{~min}$ to obtain a homogenous slurry. Temperature, $\mathrm{pH}$ and conductivity of the samples were then measured [22]. Total organic matter (TOM) was determined on $1 \mathrm{~g}$ soil/sediment sample by titrating with $0.5 \mathrm{M}$ ferrous sulphate solution, following treatment with conc. $\mathrm{H}_{2} \mathrm{SO}_{4}(99.9 \%$ pure, Sigma-Aldrich) and potassium dichromate solution [22, 23]. Particle size distribution (i.e. the relative amount of sand, silt and clay) of the samples was determined via the standard hydrometer method described by Sheldrick and Wang [24].

\subsection{Digestion of water, sediment, soil and biota samples}

One hundred (100) $\mathrm{ml}$ of water, subsampled from the acidified bulk, was filtered through $0.45 \mathrm{~mm}$ Millipore membrane and $10 \mathrm{ml}$ of aqua regia $\left(\mathrm{HNO}_{3}: \mathrm{HCl}, 1: 3\right)$ was added to the filtrate. The mixture was heated on a hot plate at $120^{\circ} \mathrm{C}$ to concentrate it down to a volume of $10 \mathrm{~mL}$. It was then cooled and made up to mark in a $50 \mathrm{~mL}$ standard flask with distilled-deionized water. $1 \mathrm{~g}$ of soil or sediment (subsampled by quartering technique from the sieved bulk) was placed in a digestion flask, and $10 \mathrm{~mL}$ of conc. $\mathrm{HNO}_{3}$ and $5 \mathrm{~mL}$ of $30 \% \mathrm{H}_{2} \mathrm{O}_{2}$ were added. The mixture was allowed to stand for $30 \mathrm{~min}$ at room temperature and then heated slowly on a hot plate to a volume of about $1 \mathrm{~mL}$ (avoiding complete dryness). Addition of the two acids was repeated and the mixture was heated again until a $1 \mathrm{~mL}$ clear or light coloured solution was obtained [25]. The mixture was cooled, filtered and made up to $50 \mathrm{~mL}$ with distilled-deionized water. Digestion of each water, sediment and soil sample was performed in triplicate.

Biota samples ( $1 \mathrm{~g}$ each) were digested by adding $10 \mathrm{~mL}$ of $3: 1$ mixture of conc. $\mathrm{HNO}_{3}$ and $\mathrm{HClO}_{4}(99.9 \%$ pure based on trace metals content, Sigma-Aldrich) and allow-

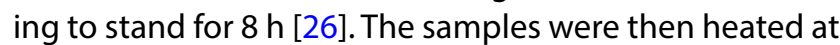
$120^{\circ} \mathrm{C}$ for $1 \mathrm{~h}$, cooled, and diluted to $50 \mathrm{ml}$ with distilleddeionized water. Three individual samples of each species caught from the lagoon were digested separately in each case.

\subsection{Trace metals analysis and method quality control}

Aqueous solution of the samples from digestion were analysed by atomic absorption spectrophotometry (Buck Scientific VGP 210 model) equipped with a graphite furnace. The instrument was calibrated with 5-point standards in the range $0.01-0.5 \mathrm{mg} / \mathrm{L}$ for all the metals, except $\mathrm{Zn}$, which was calibrated in the range 0.1 to $2 \mathrm{mg} / \mathrm{L}$. The standards were prepared from stocks $(1000 \mathrm{mg} / \mathrm{L})$ supplied by Sigma Aldrich, UK. Limits of detection (LODs) were obtained by analyzing low concentration standards of each metal and comparing the signal generated with the background/noise from procedural blanks. LODs determined gave signal/noise value of at least 3, and were $0.5 \mu \mathrm{g} / \mathrm{L}$ for As and $\mathrm{Hg} ; 0.25 \mu \mathrm{g} / \mathrm{L}$ for $\mathrm{Pb}, \mathrm{Cr}$ and $\mathrm{Zn}$; and $0.05 \mu \mathrm{g} / \mathrm{L}$ for $\mathrm{Cd}$. Deionized distilled water was used throughout the analytical work, and all containers and glassware were washed severally with $20 \%$ nitric acid, rinsed many times with deionized water and oven-dried prior their use.

The analytical procedure was validated by digesting and analyzing PACS-2 Marine Sediment Certified Reference Material for trace metals (PACS-2-CRM), produced by National Research Council of Canada. Table 1 shows certified values for each metal and the observed mean values from 3 independent replicate analyses in this study. The experimental mean values show good agreement with certified values, with accuracy ranging from 93.4 to $98.6 \%$.

\subsection{Statistical analyses}

Spearman's correlation analysis was performed to examine any association among the metals determined in 
Table 1 Certified and experimental concentration $(\mathrm{mg} / \mathrm{kg})$ of trace metals in reference sample, PACS-2-CRM

\begin{tabular}{llll}
\hline Metal & Certified values & Experimental values $^{\text {a }}$ & Accuracy (\%) \\
\hline As & 26.2 & $25.3 \pm 1.31$ & 96.6 \\
$\mathrm{Cd}$ & 2.11 & $1.97 \pm 0.15$ & 93.4 \\
$\mathrm{Cr}$ & 90.7 & $87.3 \pm 4.13$ & 96.3 \\
$\mathrm{Hg}$ & 3.04 & $2.90 \pm 0.25$ & 95.4 \\
$\mathrm{~Pb}$ & 183 & $175 \pm 6$ & 95.6 \\
$\mathrm{Zn}$ & 364 & $359 \pm 11$ & 98.6 \\
\hline
\end{tabular}

${ }^{a}$ Values are mean \pm standard deviation of 3 independent replicates

each matrix. Correlation between metals concentration in water and the physicochemical characteristics of the lagoon water, as well as between metals concentration in soil/sediment and the physicochemical characteristics of the soil/sediment samples was also examined. All analyses were performed with SPSS (IBM version 25).

\section{Results and discussion}

Table 2 shows the physicochemical characteristics of the lagoon water at the various sampling points. $\mathrm{pH}$ values are close to neutral and reflect the range expected for natural water. Temperatures measured for the water samples ranged between 29.7 and $30.1{ }^{\circ} \mathrm{C}$, exceeding the ambient value, and also higher than the maximum of $28.1^{\circ} \mathrm{C}$ reported for rivers and surface waters within the same geographical zone $[27,28]$. This slightly elevated temperature of the lagoon water close to the thermal power plant suggests an influence of the cooling water emptied by the plant into the lagoon. Indeed, a 2019 study conducted on the lagoon at Epe and Badagry locations, several kilometers away from the power plant, and at the same rainy period of the year as the current study, revealed average temperatures of 27.3 and $27.6{ }^{\circ} \mathrm{C}$, respectively [29], indicating that values recorded close to the power plant are slightly and unusually high.

Conductivity of the water samples was very high, ranging from 6270 to $7580 \mu \mathrm{S} / \mathrm{cm}$. The conductivity values are consistent with the brackish nature of the studied lagoon environment in comparison with values reported for freshwater bodies in the country, such as Ogun river, 99-180 $\mu \mathrm{S} / \mathrm{cm}$ [30]; Owena dam, 107-150 $\mu \mathrm{S} / \mathrm{cm}$ [31]; Oban Massif, 16-64 $\mu \mathrm{S} / \mathrm{cm}$ [32]; and Ubogo and Egini rivers, 8-48 $\mu \mathrm{S} /$ $\mathrm{cm}$ [33]. As expected, total dissolved solids (TDS) measured in the samples are in agreement with the conductivity values-sampling point $\mathrm{W} 1$ with the least TDS content gave the least conductivity value, while W4 with the highest TDS also had the highest conductivity. Given that W1 is the sampling location closest to the thermal power plant and W5 is the farthest, the TDS values, as well as total suspended solids (TSS) values, showed no apparent trend relative to the position of the plant. In effect, no consistent decrease or increase in TDS or TSS values was observed with distance away from the plant. Consequently, total solids (TDS + TSS) also did not show any relationship with the location of the power plant. The results imply that the operation of the plant does not cause the release of any materials which 'significantly' alter the solid contents of the lagoon water within the section investigated. The TDS values are mostly below the maximum limit $(500 \mathrm{mg} / \mathrm{L}$ ) stipulated by the United States Environment Protection Agency (USEPA), except at location W4 where higher value was recorded.

Dissolved oxygen (DO) values in the water samples ranged between 5.1 and $8.2 \mathrm{mg} / \mathrm{L}$ (Table 2). The results show that the DO content increases gradually with distance on the lagoon, away from the thermal power plant. The lower DO content of the lagoon water close to the power station may have deleterious impact on the metabolism, reproduction, longevity and growth
Table 2 Physicochemical characteristics (PCC) of the lagoon water samples

\begin{tabular}{llllll}
\hline PCC & W1 & W2 & W3 & W4 & W5 \\
\hline pH & 6.67 & 6.63 & 6.70 & 6.77 & 7.08 \\
Temperature $\left({ }^{\circ} \mathrm{C}\right)$ & 29.7 & 29.9 & 30.1 & 29.9 & 30.1 \\
Conductivity $(\mathrm{HS} / \mathrm{cm})$ & $6270 \pm 3$ & $6800 \pm 5$ & $7080 \pm 5$ & $7580 \pm 8$ & $7470 \pm 6$ \\
Total alkalinity $(\mathrm{mg} / \mathrm{L})$ & $42.3 \pm 1.67$ & $54.3 \pm 1.71$ & $46.6 \pm 1.61$ & $41.3 \pm 1.95$ & $50.1 \pm 1.77$ \\
Total solid (mg/L) & $282 \pm 0.50$ & $362 \pm 0.80$ & $466 \pm 0.20$ & $605 \pm 0.20$ & $530 \pm 0.50$ \\
TDS (mg/L) & $247 \pm 2.40$ & $345 \pm 2.10$ & $430 \pm 1.80$ & $570 \pm 0.50$ & $490 \pm 1.30$ \\
TSS (mg/L) & $35.6 \pm 2.45$ & $17.3 \pm 2.24$ & $36.1 \pm 1.81$ & $35.2 \pm 0.54$ & $40.8 \pm 1.39$ \\
Dissolved oxygen (mg/L) & $5.1 \pm 0.02$ & $6.2 \pm 0.01$ & $7.2 \pm 0.03$ & $8.1 \pm 0.03$ & $8.2 \pm 0.02$ \\
BOD (mg/L) & $3.0 \pm 0.01$ & $8.9 \pm 0.02$ & $5.0 \pm 0.01$ & $10.0 \pm 0.03$ & $19.7 \pm 0.03$ \\
COD (mg/L) & $11.9 \pm 0.50$ & $15.0 \pm 0.35$ & $5.9 \pm 0.18$ & $63.5 \pm 0.70$ & $85.3 \pm 0.30$ \\
\hline
\end{tabular}

TDS total dissolved solids, TSS total suspended solids, BOD biological oxygen demand, $C O D$ chemical oxygen demand 
of organisms inhabiting the water [34]. The lower DO content observed near the power plant appears to be a consequence of the elevated temperature at this section of the lagoon. However, an opposing relationship expected between DO and temperature was not consistent throughout the sampling points, possibly due to variation of other factors such as pressure, salt content of the water, rate of diffusion, as well as the distribution of oxygen-consuming and photosynthetically active species in the water, all of which also influence the DO content $[35,36]$. As expected, chemical oxygen demand (COD) values were all higher than biological oxygen demand (BOD) values of the lagoon water at each sampling point. However, both showed different trends over the sampled section. For COD, value measured at point W5 $>$ W4 $>$ W2 $>$ W1 $>$ W3, while the pattern observed for BOD was W5 $>$ W4 $>$ W2 $>$ W3 $>$ W1. Neither of these two parameters showed any consistent trend with respect to the location of the power plant.

As for the water samples, physicochemical characteristics of the sediments taken at points SD1, SD2, SD3, SD4 and SD5 (corresponding to the water sampling points W1, W2, W3, W4 and W5, respectively) were determined, and results are presented in Table 3. Sediment temperatures were fairly constant around $29^{\circ} \mathrm{C}$ and reflect the status of the lagoon water with which they are in regular contact. The conductivity property of the sediments also shows similar variation to the conductivity of the water samples over the entire five locations (i.e. SD4 > SD5 > SD3 > SD2 > SD1 in both phases), suggesting that the level of dissolved salts in water at each location influences the level salts present in the corresponding sediment. Particle size distribution of the sediments (shown as percentages of clay, sand and silt) reveal that they belong mainly to the very slightly silty-slightly clayey-Sand (vsi)(c)S type, based on standard sediment textural classification [37], although clay contents of samples SD2 and SD3 marginally exceeded the $20 \%$ mark for transitioning to clayey sands. Overall, results shown in the Table 3 indicate that none of the physicochemical parameters of the sediments shows a consistent trend with respect to the location of the power plant on the lagoon, confirming that the operations of the plant have no influence on the characteristics of the proximal lagoon sediments.

Concentration of trace metals in the lagoon water samples and sediments are presented in Fig. 2. All the metals analysed ( $\mathrm{As}, \mathrm{Cd}, \mathrm{Cr}, \mathrm{Hg}, \mathrm{Pb}$ and $\mathrm{Zn}$ ) were present in the lagoon water at all sampling points. In general, $\mathrm{Zn}$ occurred at highest levels in the water samples, with the order of magnitude for all the metals being: $\mathrm{Zn}>\mathrm{Cd}>$ $\mathrm{Hg}>\mathrm{Pb}>\mathrm{Cr}>\mathrm{As}$ (as revealed by the mean concentration over all the sampling points). However, it should be noted that the levels of $Z n$ in this section of the lagoon are well within the maximum limits stipulated for water $(5 \mathrm{mg} / \mathrm{L})$, whereas the average concentration of $\mathrm{Cd}, \mathrm{Pb}$ and $\mathrm{Hg}$ exceeded their limits of $0.005,0.015$ and $0.002 \mathrm{mg} / \mathrm{L}$, respectively [38]. More importantly, results shown in Fig. 2 reveal a number of trends which provide insight into the possible impacts of the power plant's operations on the concentration of trace metals detected in the lagoon water. Firstly, apart from the less toxic $\mathrm{Zn}$, the highest concentration of each of the metals was measured at the first sampling point on the lagoon, closest to the location of the power plant. Secondly, the concentration of As, Cd, Cr and Pb decreases steadily over the sampling area, being highest at the sampling location closest to the power plant (point 1) and lowest at point 5 in each case. Although cooling water from the power plant is discharged into the lagoon on the side opposite the accessible section, from where samples were taken; these results and trend obtained for the metals strongly suggest that the massive countercurrent movement of water and turbulent exchanges due to strong wind, causes transfer of pollutant materials across the whole area surrounding the plant. Indeed, correlation analyses performed to examine association among the trace metals in the lagoon water revealed strong positive correlations among $\mathrm{As}, \mathrm{Cr}$ and $\mathrm{Pb}$ levels in the lagoon water (Online Resource, Table S6). The most probable sources of As in the power plant's operations are natural gas and fuel oil, both known to contain As compounds [39-41]. These are combusted to generate steam in the power plant, and under such uses, As emissions have been found [42]. The fuels may also be
Table 3 Physicochemical characteristics (PCC) of the lagoon sediments

\begin{tabular}{llllll}
\hline PCC & SD1 & SD2 & SD3 & SD4 & SD5 \\
\hline pH & 6.57 & 7.12 & 5.82 & 6.74 & 6.78 \\
Temperature $\left({ }^{\circ} \mathrm{C}\right)$ & 29.9 & 29.6 & 29.4 & 29.7 & 29.7 \\
Conductivity $(\mu \mathrm{S} / \mathrm{cm})$ & $310 \pm 6$ & $354 \pm 3$ & $372 \pm 7$ & $426 \pm 5$ & $396 \pm 3$ \\
Clay $(\%)$ & $19.6 \pm 1.03$ & $20.3 \pm 0.85$ & $20.1 \pm 1.14$ & $19.5 \pm 1.07$ & $19.1 \pm 0.96$ \\
Sand $(\%)$ & $77.9 \pm 2.07$ & $77.1 \pm 1.83$ & $77.2 \pm 1.98$ & $78.3 \pm 1.57$ & $78.3 \pm 1.82$ \\
Silt $(\%)$ & $2.40 \pm 0.16$ & $2.45 \pm 0.25$ & $2.70 \pm 0.08$ & $2.14 \pm 0.11$ & $2.61 \pm 0.37$ \\
Organic matter $(\%)$ & $0.67 \pm 0.03$ & $1.85 \pm 0.11$ & $0.24 \pm 0.07$ & $0.34 \pm 0.07$ & $0.87 \pm 0.04$ \\
\hline
\end{tabular}

SN Applied Sciences 
Fig. 2 Variation in concentration of trace metals over sampling points ( 1 to 5 ) of the Lagos lagoon water (a) and sediments (b). Point 1 is closest to the Egbin power plant; point 5 is farthest from the plant. Error bars represent standard deviations from triplicate determinations
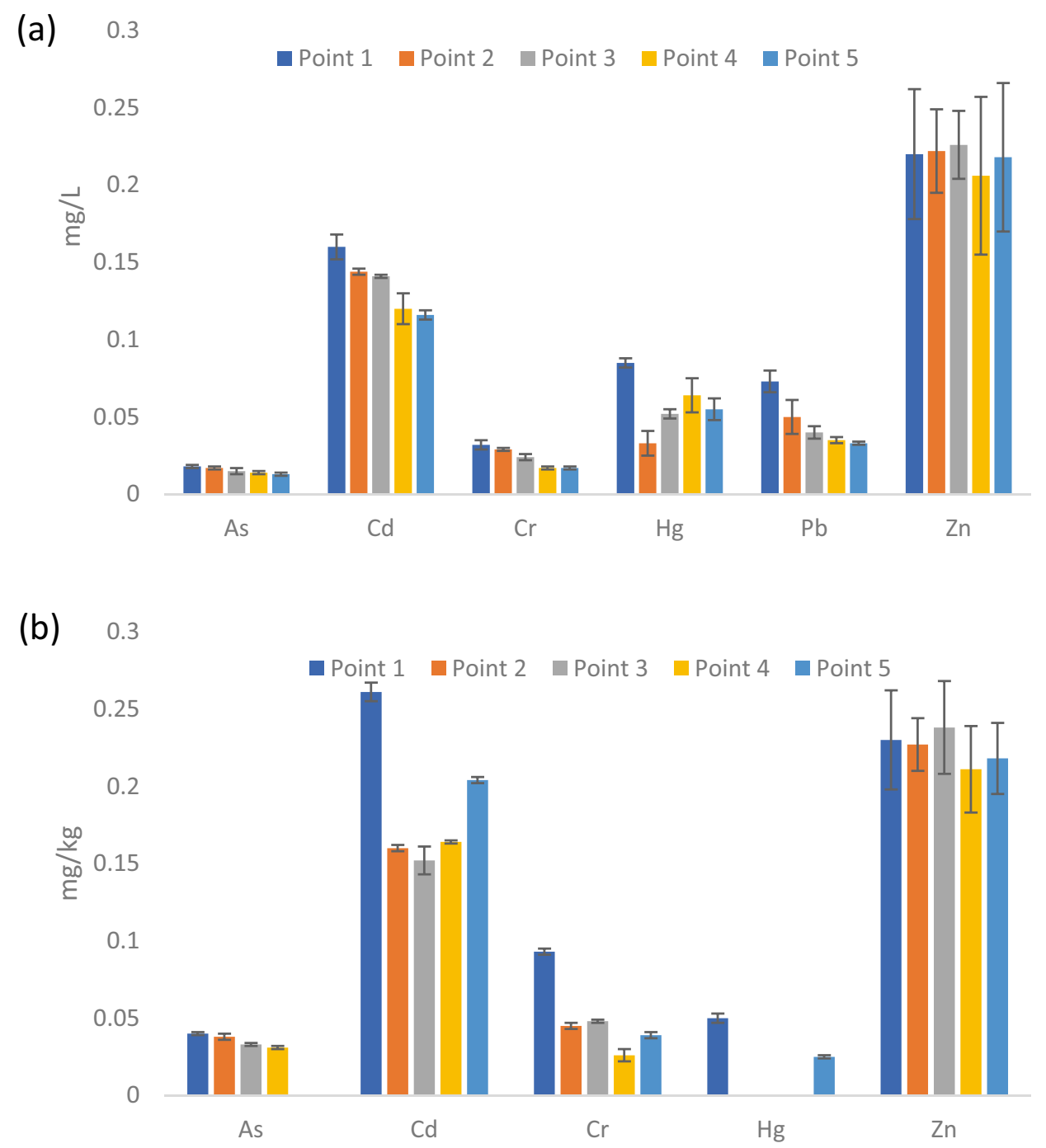

implicated in the release of $\mathrm{Pb}$ and $\mathrm{Cd}$ from this power plant. It has long been established that $\mathrm{As}, \mathrm{Pb}, \mathrm{Cd}$ and $\mathrm{Hg}$ are easily volatilized and released from high-temperature combustion processes, such as found in the operation of this power plant [43]. Combustion of fuel oil is the likely source of $\mathrm{Cr}$ from the plant's operations, since certain levels of $\mathrm{Cr}$ metal are often associated with fuel oils, and are released following their combustion [44, 45]. In addition, $\mathrm{Cr}$ may have emanated from the regular contact of steam, hot water and hot waste streams with metallic surfaces in the power plant, causing the metal to leach into the fluids. $\mathrm{Cr}$ is used extensively for oxidation resistance and corrosion prevention in power plant materials, and also added to cooling water used for steam condensation $[3,46,47]$. Although the Egbin power company makes efforts to adhere to regulations by treating waste waters and flue gases, this study reveals the impact of trace metallic contaminants which remain in the waste streams that are regularly released into the open environment.

Concentration of the trace metals determined in sediments at the corresponding water sampling points are also presented in Fig. 2. $\mathrm{Pb}$ was not detected in all the sediment samples while $\mathrm{Hg}$ was found only at point 1 $(0.05 \mathrm{mg} / \mathrm{kg})$, closest to the power plant, and at point $5(0.025 \mathrm{mg} / \mathrm{kg})$. With the exception of $\mathrm{Hg}$, levels of the metals in the sediments exceeded those in the lagoon water at corresponding sampling points. As observed for the water samples, concentration of all the metals were highest at the first sampling point. Furthermore, highest As concentration was measured in point 1 sediment, with the value decreasing gradually with distance away from the power plant, similar to the trend observed for the four metals ( $\mathrm{As}, \mathrm{Cd}, \mathrm{Cr}$ and $\mathrm{Pb}$ ) in the lagoon water. However, it is not yet clear why $\mathrm{Cd}$ and $\mathrm{Cr}$ found in the sediments did not follow the same trend observed for them in the water. 
Correlation analyses performed to examine association (if any) between the levels of the different metals measured in the lagoon water (Online Resource, Table S5) suggest association between $\mathrm{Cd}$ and $\mathrm{Hg}$, as well as between $\mathrm{Cr}$ and $\mathrm{Hg}$.

Concentrations of the metals in Tilapia fish (Oreochromis niloticus), lagoon crab (Callinectes amnicola) and shrimp (Penaeus notalis), caught within the section of the lagoon investigated, are shown in Table 4. All the metals were detected in the biota, with the exception of $\mathrm{Hg}$ and $\mathrm{Pb}$, which were not detected in the fish samples. Being one of the protein deficient nations of the world, a good proportion of the Nigerian people, particularly the rural and coastal-dwelling populace, depend on these foods as sources of protein [48]. Indeed, the species analysed in this study are caught in commercial quantities and sold directly to members of the public in the area. Thus, the presence of trace metals in these organisms represent a route of continuous human exposure to sub-lethal levels of the metals, many of which have been implicated in several health problems, including cancer, mental retardation, psychosis, dyslexia, birth defects, paralysis, muscular weakness, brain damage, hypertension, nervous disorders, fatigue and renal dysfunction $[49,50]$. Particularly worthy of note is the high level of $\mathrm{Cd}$ found in the biota species. For example, the average concentration of $0.13 \mathrm{mg} / \mathrm{kg}$ determined for fish samples is more than twice the maximum permissible concentration stipulated by the Food and Agricultural Organization [51]. Bioaccumulation factors (BF) for the trace metals in biota samples (Online Resource, Table S2) were calculated relative to the average concentration of the metals in the lagoon water for Oreochromis niloticus, and relative to the average concentration of the metals in the sediments for the bottom-dwelling organisms, Callinectes amnicola and Penaeus notalis. The results indicate that $\mathrm{Cd}, \mathrm{Hg}, \mathrm{Pb}$ and $\mathrm{Zn}$ bioaccumulate in both Callinectes amnicola and Penaeus notalis, while only $\mathrm{Zn}$ bioaccumulates in Oreochromis niloticus (BF $>1$ in all cases).

Trace metals present in topsoil are often associated with anthropogenic sources, compared to those present in the subsoil, which are known to result from pedogenetic (lithogenic) process of weathering of the soil parent materials [52, 53]. Topsoil and subsoil samples from land near the power plant and adjacent to the various sampling points on the lagoon (see Fig. 1) were analysed for their trace metals content, in order to assess possible anthropogenic contribution of the power plant, via atmospheric deposition of metals in flue wastes. Figure 3 presents the concentration of the metals determined in the adjacent soil samples for the corresponding points 1 to 5 , as well as the values determined in topsoil and subsoil of a control sample $\left(\mathrm{S}_{\mathrm{ctr}}\right)$, taken from the same ljede community, but farther away from the power plant's location. $\mathrm{Hg}$ and $\mathrm{Pb}$ were not detected in both topsoil and subsoil samples of the control soil, and in samples 1 to 5 proximal to the plant. $\mathrm{Cr}$, which was absent in all the 5 subsoil samples and in both topsoil and subsoil of the control sample, was detected in a decreasing trend in the topsoil samples 1 to 5 , the magnitude being highest at the first sampling point closest to the power plant.

Presence of the metal $\mathrm{Cr}$ in the topsoil samples (and absence in the subsoil and control samples) strongly point to the role of atmospheric deposition of $\mathrm{Cr}$-containing pollutants from the power plant in the presence of the metal in proximal topsoils. Arsenic (As) was found in the three top soil samples closest to the power plant, and at levels which appear to decrease as the distance increased away from the plant. The metal was not present in the subsoil sample at point 1 , but was found in all other subsoil samples. This, coupled with the fact that the metal was also detected in the control sample, farther away from the power plant, means that its presence may not be attributed to the plant's operations alone. Also, $\mathrm{Cd}$ and $\mathrm{Zn}$ were detected in most of the topsoil samples 1 to 5 , but their levels showed no specific relationship or trend with respect to the position of the power plant, indicating that atmospheric deposition from the power plant did not significantly determine the levels of these metals in the nearby soil environment. Correlation analyses performed to examine association between trace metals concentration and physicochemical characteristics of topsoil and subsoil (Online Resource, Tables S3 and S4) suggest that $\mathrm{Cr}$ presence in the topsoil may be associated with the particle size composition, particularly the sand content of the topsoil (Online Resource, Tables S7 and S8). This observation
Table 4 Trace metals concentration $(\mathrm{mg} / \mathrm{kg})$ in biota $^{a}$

\begin{tabular}{lllllll}
\hline Biota & $\mathrm{As}$ & $\mathrm{Cd}$ & $\mathrm{Cr}$ & $\mathrm{Hg}$ & $\mathrm{Pb}$ & $\mathrm{Zn}$ \\
\hline Crab (Callinectes amnicola) & 0.014 & 0.445 & 0.017 & 0.113 & 0.017 & 1.39 \\
Shrimp (Penaeus notalis) & 0.015 & 0.359 & 0.033 & 0.075 & 0.022 & 1.31 \\
Fish (Oreochromis niloticus) & 0.012 & 0.131 & 0.020 & - & - & 0.78 \\
\hline
\end{tabular}

aValues are mean of analyses of three samples of each species from the lagoon; "-" Represents no detection. Standard deviations associated with the measurements are provided in the Online Resource (Table S1) 
Fig. 3 Concentration of trace metals in topsoil (a) and subsoil (b) samples from points 1 to 5 near the Egbin power plant and from a control point located farther $(6 \mathrm{~km})$ away from the plant. Point 1 is closest to the Egbin power plant; point 5 is farthest from the plant. Error bars represent standard deviations from triplicate determinations
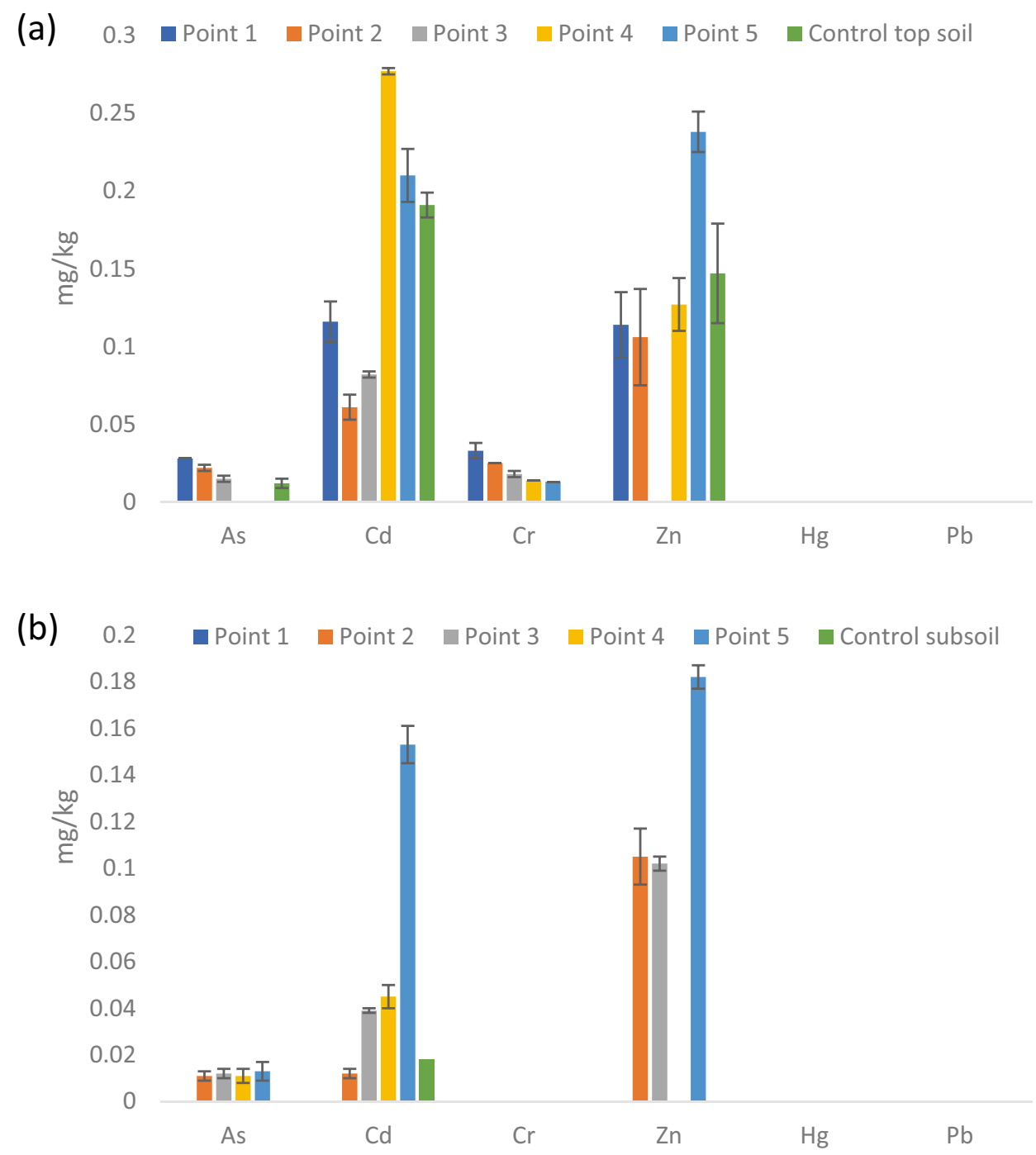

is consistent with previous report by Zayed and Terry [54] and Oliveira [55] that sand particles tend to adsorb and retain higher levels of $\mathrm{Cr}$ than soils with low sand content. A strong positive correlation was observed between $\mathrm{pH}$ values and $\mathrm{Zn}$ levels in the subsoil, indicating that more $\mathrm{Zn}$ is retained in the subsoil as $\mathrm{pH}$ tends towards neutral.

\section{Conclusions}

This study has investigated the impact of Egbin power plant on the physicochemical characteristics and levels of trace metals in the lagoon water, sediment, biota and the proximal soil environment. Of all the physicochemical characteristics of the lagoon water determined, only temperature effect is directly traceable to the operations of the thermal power plant, and this consequently influenced the levels of dissolved oxygen in the water near the power plant. The physicochemical properties of the lagoon sediment and the soil (land) adjacent the lagoon were not affected by the activities of the power plant. On the other hand, atmospheric deposition of pollutants from the plant had a profound impact on $\mathrm{Cr}$ presence in the proximal soil. Levels of $\mathrm{As}, \mathrm{Cd}, \mathrm{Cr}$ and $\mathrm{Pb}$ in the lagoon water were influenced by the plant's operations. As, $\mathrm{Cd}, \mathrm{Cr}, \mathrm{Hg}, \mathrm{Pb}$ and $\mathrm{Zn}$ were all detected in tilapia, shrimps and crabs, with $\mathrm{Cd}, \mathrm{Hg}$, $\mathrm{Pb}$ and $\mathrm{Zn}$ bioaccumulating in the shrimps and crabs. This has health implications for both the biota and the human population who feed on these organisms in the area. This study would be very valuable for future progressive monitoring of the impacts of Egbin power plant on the surrounding water, sediment, biota and land. Given the amount and intensity of sunlight received all-year-round in the country, and indeed the entire Tropical-African region, a cleaner and more sustainable approach to electricity generation would be solar photovoltaic technologies or solar thermal power systems, other than the combustion of natural gas and fuel-oil, which results in environmental 
contamination. In the meantime, commercial sales of sea foods caught from the lagoon should be discouraged and discontinued in the interest of public health.

Acknowledgements The authors are grateful to the Department of Biology, Federal University of Technology Akure (FUTA), Nigeria, for help with identification of the biota species. Authors also wish to thank Technologists in the Department of Chemistry and in Central Research Laboratory of FUTA, for technical assistance rendered.

Author contributions GAl, conceptualization, study design, analyses, investigation, data curation, project administration, analyses, supervision, writing-original draft, writing - review and editing. EAO, analyses, investigation, data curation, writing - original draft. AMI, analyses, data curation, writing - original draft, writing — review and editing. AFA, conceptualization, study design, project administration, resources, supervision, writing-review and editing.

\section{Compliance with ethical standards}

Conflict of interest The authors declare that they have no known competing interests that could have appeared to influence the work reported in this paper.

\section{References}

1. Liu Z (2015) Building global energy interconnection. In: Liu Z (ed) Global energy interconnection. Elsevier Inc., Amsterdam, p 195

2. Maza-Ortega JM, Acha E, García S, Gómez-expósito A (2017) Overview of power electronics technology and applications in power generation, transmission and distribution. J Mod Power Syst Clean Energy 5:499-514

3. Mohsen MS (2004) Treatment and reuse of industrial effluents: case study of a thermal power plant. Desalination 167:75-86

4. International Energy Agency, IEA (2018) Key world energy statistics 2018. p 14

5. Liang Y, Yu B, Wang L (2019) Costs and benefits of renewable energy development in China's power industry. Renew Energy 131:700-712

6. Amin YM, Khandaker MU, Shyen AKS, Mahat RH, Nor RM, Bradley DA (2013) Radionuclide emissions from a coal-fired power plant. Appl Radiat Isot 80:109-116

7. Dragović S, Ćujić M, Slavković-Beškoski L, Gajić B, Bajat B, Kilibarda M, Onjia A (2013) Trace element distribution in surface soils from a coal burning power production area: a case study from the largest power plant site in Serbia. CATENA 104:288-296

8. Janković MM, Todorović DJ, Nikolić JD (2011) Analysis of natural radionuclides in coal, slag and ash in coal-fired power plants in Serbia. J Min Metall Sect B 47(2):149-155

9. Mishra UC (2004) Environmental impact of coal industry and thermal power plants in India. J Environ Radioact 72(1):35-40

10. Nalawade PM, Bholay AD, Mule MB (2012) Assessment of groundwater and surface water quality indices for heavy metals nearby area of Parli thermal power plant. Univ J Environ Res Technol 2(1):47-51

11. Raja R, Nayak AK, Shukla AK, Rao KS, Gautam P, Lal B, Tripathi R, Shahid M, Panda BB, Kumar A, Bhattacharyya P, Bardhan G, Gupta S, Patra DK (2015) Impairment of soil health due to fly ash-fugitive dust deposition from coal-fired thermal power plants. Environ Monit Assess 187:679. https://doi.org/10.1007/ s10661-015-4902-y

SN Applied Sciences
12. Tian HZ, Wang Y, Xue ZG, Cheng K, Qu YP, Chai FH, Hao JM (2010) Trend and characteristics of atmospheric emissions of $\mathrm{Hg}$, As, and Se from coal combustion in China, 1980-2007. Atmos Chem Phys 10(23):11905-11919

13. Yang B, Gu J, Zhang T, Zhang KM (2019) Near-source air quality impact of a distributed natural gas combined heat and power facility. Environ Pollut 246:650-657

14. Fouladi Fard R, Naddafi K, Yunesian M, Nabizadeh Nodehi R, Dehghani MH, Hassanvand MS (2016) The assessment of health impacts and external costs of natural gas-fired power plant of QOM. Environ Sci Pollut Res 23:20922-20936

15. Di Ciaula A (2012) Emergency visits and hospital admissions in aged people living close to a gas-fired power plant. Eur J Int Med 23(2):53-58

16. John W, Sakwari G, Mamuya SH (2018) Noise exposure and self-reported hearing impairment among gas-fired electric plant workers in Tanzania. Ann Global Health 84(3):523-531

17. Emovon I, Kareem B, Adeyeri MK (2011) Performance evaluation of Egbin thermal power station, Nigeria. In: Proceedings of the world congress on engineering and computer science (WCECS 2011), vol II, San Francisco, pp 1-5

18. Ogieva FE, Ike AS, Anyaeji CA (2015) Egbin power station generator availability and unit performance studies. Int J Phys Sci 10(4):155-172

19. Anheier HK, Isar YR (2012) Cultures and globalization: cities, cultural policy and governance. SAGE Publishing, New York, pp 117-119

20. Emmanuel BE, Chukwu LO (2010) Spatial distribution of saline water and possible sources of intrusion into a tropical freshwater lagoon and the transitional effects on the lacustrine ichthyofaunal diversity. Afr J Environ Sci Technol 4(7):480-491

21. Ademoroti CMA (1996) Standard methods for water and effluent analysis. Foludex Press, Ibadan

22. Maduawuchi CO, Idowu GA, Aiyesanmi AF (2019) Impact of fluvial deposition on potential toxic metals burden of selected floodplains in Southwestern Nigeria. Environ Earth Sci 78:561. https://doi.org/10.1007/s12665-019-8574-8

23. Schulte EE (1995) Recommended soil organic matter tests. In: Sim JT, Wolf AM (eds) Recommended soil test procedure for the North Eastern USA. Northern Regional Publication No. 493. Agricultural experiment station, University of Delaware, Newark, pp 65-74

24. Sheldrick BH, Wang C (1993) Particle size distribution. In: Carter MR (ed) Soil sampling and methods of analysis. Canadian Society of Soil Science. Lewis, London, pp 499-517

25. Vodopivez C, Curtosi A, Pelletier E, Spairani LU, Hernández EA, Mac Cormack WP (2019) Element concentrations of environmental concern in surface sediment samples from a broad marine area of 25 de Mayo (King George) Island, South Shetland Islands. Sci Total Environ 646:757-769

26. Rashed MN (2001) Monitoring of environmental heavy metals in fish from Nasser Lake. Environ Int 27(1):27-33

27. Oketola AA, Fagbemigun TK (2013) Determination of nonylphenol, octylphenol and bisphenol-A in water and sediments of two Major rivers in Lagos, Nigeria. J Environ Prot 4:38-45

28. Oketola AA, Osibanjo O, Ejelonu BC, Oladimeji YB, Damazio OA (2006) Water quality assessment of river Ogun around the cattle market of Isheri. Nigeria J Appl Sci 6(3):511-517

29. Ukenye EA, Taiwo IA (2019) Studies on the physico chemical status and biological characteristics of some rivers in Nigerian coastal states. Int J Fisher Aquatic Stud 7(3):192-196

30. Dimowo BO (2013) Assessment of some physico-chemical parameters of river Ogun (Abeokuta, Ogun State, Southwestern Nigeria) in comparison with national and international standards. Int J Aquac 3(15):79-84 
31. Oyhakilome GI, Aiyesanmi AF, Akharaiyi FC (2012) Water quality assessment of the Owena multi-purpose dam, Ondo State, Southwestern Nigeria. J Environ Prot 3:14-25

32. Ugbaja AN, Ephraim BE (2019) Physicochemical and bacteriological parameters of surface water quality in part of Oban Massif, Nigeria. Global J Geol Sci 17:13-24

33. Ejoh AS, Unuakpa BA, Ibadin FH, Edeki SO (2018) Dataset on the assessment of water quality and water quality index of Ubogo and Egini rivers, Udu LGA, Delta State Nigeria. Data in Brief 19:1716-1726

34. Foley B, Jones ID, Maberly SC, Rippey B (2012) Long term changes in oxygen depletion in a small temperate lake: effects of climate change and eutrophication. Freshw Biol 57:278-289

35. Deacutis CF (2016) Dissolved oxygen. In: Kennish MJ (ed) Encyclopedia of Estuaries. Encyclopedia of earth sciences series. Springer, Dordrecht

36. Prasad BSRV, Srinivasu PDN, Sarada Varma P, Raman AV, Ray S (2014) Dynamics of dissolved oxygen in relation to saturation and health of an aquatic body: a case for Chilka Lagoon. India J Ecosyst. https://doi.org/10.1155/2014/526245

37. Blott SJ, Pye K (2012) Particle size scales and classification of sediment types based on particle size distributions: Review and recommended procedures. Sedimentology 59:2071-2096

38. United States Environmental Protection Agency (2012) 2012 edition of the drinking water standards and health advisories, EPA 822-S-12-001, Washington, DC. Accessed 26 Nov 2019, https:// rais.ornl.gov/documents/2012

39. Delgado-Morales W, Zingaro RA, Mohan MS (1994) Arsenic in natural gas: Analysis and characterization of pipeline solids by ${ }^{1} \mathrm{H}$ NMR and other methods. Int J Environ Anal Chem 57(4):313-328

40. Liu ZX, Tang DZ, Yan QT, Xu H, Wang SY, Xu R, Wu S (2014) Characteristic of the volatile arsenic in natural gas and its novel determination method. Appl Mech Mater 522-524:1515-1521

41. Puri BK, Irgolic KJ (1989) Determination of arsenic in crude petroleum and liquid hydrocarbons. Environ Geochem Health 11:95-99

42. United States Environmental Protection Agency (1998) Locating and estimating air emissions from sources of arsenic and arsenic compounds, EPA-454/R-98-013. Accessed 29 Nov 2019 https:// www3.epa.gov

43. Pacyna JM (1987) Atmospheric emissions of arsenic, cadmium, lead and mercury from high temperature processes in power generation and industry. In: Hutchinson TC, Meema KM (eds) Lead, mercury, cadmium and arsenic in the environment. Scope 31. Wiley, Chichester, pp 69-87
44. Galbreath KC, Zygarlicke CJ, Toman DL, Huggins FE, Huffman GP (1998) Nickel and chromium speciation of residual oil combustion ash. Combust Sci Technol 134(1-6):243-262

45. Stigter JB, de HaanR Guicherit HPM, Dekkers CPA, Daane ML (2000) Determination of cadmium, zinc, copper, chromium and arsenic in crude oil cargoes. Environ Pollut 107(3):451-464

46. Lister DH (2007) Thermal power plants (Volume 1) @Encyclopedia of Life Support Systems (EOLSS). Accessed 30 Nov 2019, https://www.desware.net/Sample-Chapters/D12/E3-10-01-07. pdf

47. Nair A, Kumanan S (2015) Newer materials for supercritical power plant components-A manufacturability study. In: Proceedings of the international conference on advances in production and industrial engineering (INCAPIE 2015), NIT Trichy, pp 326-331

48. Elegbede IO, Fashina-Bombata HA (2013) Proximate and mineral compositions of common crab species (Callinectes pallidus and Cardisoma armatum) of Badagry creek, Nigeria. Poult Fisher Wildl Sci 2:110-116

49. Jaishankar M, Tseten T, Anbalagan N, Mathew BB, Beeregowda KN (2014) Toxicity, mechanism and health effects of some heavy metals. Interdiscip Toxicol 7(2):60-72

50. Chounwou PBT, Yedjou CG, Patlolla AK, Sutton DJ (2012) Heavy metals toxicity and the environment. EXS 101:133-164

51. Food and Agriculture Organization (FAO) (2003) Heavy metal regulations legal notice No. 66/2003. Accessed 11 Apr 2020, https://extwprlegs1.fao.org/docs/pdf/eri42405.pdf

52. Tóth G, Hermann T, Szatmári G, Pásztor L (2016) Maps of heavy metals in the soils of the European Union and proposed priority areas for detailed assessment. Sci Total Environ 565:1054-1062

53. Wuana RA, Okieimen FE (2011) Heavy metals in contaminated soils: A review of sources, chemistry, risks and best available strategies for remediation. ISRN Ecol. https://doi. org/10.5402/2011/402647

54. Zayed AM, Terry N (2003) Chromium in the environment: factors affecting biological remediation. Plant Soil 249:139-156

55. Oliveira $H$ (2012) Chromium as an environmental pollutant: Insights on induced plant toxicity. J Bot. https://doi. org/10.1155/2012/375843

Publisher's Note Springer Nature remains neutral with regard to jurisdictional claims in published maps and institutional affiliations. 